\title{
SUMMARIES OF ARTICLES
}

The history of psychology as an autonomous discipline includes not only methodological and institutional developments but also the elaboration of the very concept of psychology and of the representations of its place in the order of the sciences. Although such representations do not determine the constitution of the professional or concrete practice of the psychologist, they express epistemological ideals and reflect changes in the discipline. We shall first give a general view of the position of psychology in the 17th and 18th centuries, then outline the history of its place among the sciences from Destutt de Tracy to Jean Piaget. After having been the science of sciences in hierarchical classifications, psychology integrated itself among the other sciences in less linear, and even circular patterns, without, however, always losing the epistemological and pedagogical preeminence originally given it by the "psychologists" of the 18th century.

From its foundation as a domaine of knowledge at the end of the 17th century, psychology rapidly divided itself into two tendencies with different orientations. The first, based on a naturalistic inspiration, is situated in the prolongation of the Aristotelian commentary of the Physica and develops principally in the Protestant universities of Marburg and Leyden. In these institutions where at the time a spirit of humanism, rationalism and tolerance reigned, the first form of the dualism of soul and body takes shape. But at the same period, in mystical and esoteric circles, another concept of psychology develops whose interpretative method is inspired by biblical exegesis and which develops therapeutic procedures, cures of the soul and magnetic cures, which depend on psychological influence.

Revue de synthèse: IV S. N ${ }^{\text {os }}$ 3-4, juillet-décembre 1994. 
Psychology considered as a natural science began as Aristotelian "physics" or "natural philosophy" of the soul. $C$. Wolff placed psychology under metaphysics, coordinate with cosmology. Scottish thinkers placed it within moral philosophy, but distinguished its "physical" laws from properly moral laws (for guiding conduct). Several Germans sought to establish an autonomous empirical psychology as a branch of natural science. British and French visual theorists developed mathematically precise theories of size and distance perception; they created instruments to test these theories and to measure visual phenomena such as the duration of visual impressions. These investigators typically were dualists who included mental phenomena within nature.

\section{What Is Psychology's Place in Positivism?}

Annie PetrT

"Psychology" is not integrated in the range of the sciences in Contian positivism. Comte even judges that it is the refuge of a resistant, ancient "metaphysics". Nevertheless, since "emotional, intellectual and moral phenomena" must also be studied "positively", Comte has recourse both to "biology" where he elaborates a "cerebral theory", and to "sociology" and the historical method. Then he even thinks of a new science, "moral anthropology", where can be found a large part of the questions stemming from ex-psychology.

An analysis is also made of the discussions concerning Comte with those close to him who are more or less disciplined: John Stuart Mill is severely ironical against the cerebral theory and demands a place for "logic"; Emile Littré, a more nuanced disciple, accepts a "psycho-physiology" but questions many of the developments and consequences given it by Comte.

The Banishment of Spirits. The Birth of

Françoise PAROT an Institutional Frontier between

Spiritism and Psychology

At the end of the nineteenth century, psychologists had to deal with the growing interest of scientists and the public concerning the power of survival of the spirit. During some years, they went to work with spiritualists and spiritists who were convinced of this power. To solve this crucial scientific question, psychologists engaged in several experiments (moving tables, materializations, telepathy) which have brought no scientific progress but some scandalous rumors. The history of international congresses reveals that, in order to save their discipline scientifically, they decided to build an official frontier between psychology and spiritism; but some psychologists continuously overcame clandestinely that frontier. 
Sociology and Psychology in France,

Laurent MuCCHIELLI the Appeal for a Common Territory: Towards a Collective Psychology (1890-1940)

As its official history would have it, French social psychology after being borm and having died at the end of the nineteenth century, went through a long eclipst before coming back to life in the fifties under American influence. This disappearance in the first half of the twentieth century was supposedly caused by the domi. nation of Durkheimian sociology which was said to be hostile towards psychology. This article questions this traditional vision. It shows that Durkheimian sociolog) defined itself as a collective psychology and that it was able from the 1910's onwards to begin a true dialogue with the psychologists within the university. The Durkheimian theory, according to which the most fundamental categories of thought are already social constructions, created a real intellectual shock among psychologists. Indeed, it compelled them to leave the narrow field of psychophysiology that founders such as Taine or Ribot had been promoting in reaction against spiritualism since 1870. This new collective psychology influenced most of the great psychologists of the time (Blondel, Janet, Meyerson, Wallon), yet it lacked time and men to become institutionalized. As a result, it vanished with the death of its main architects (Blondel and Halbwachs) and with their successors' more or less intentional neglect.

\section{Between Neuroscience and Cognitive Psychology : A Frontier in Question}

Alain TÊTE

The emergence of connectionist models in the 1980's modified the boundary between neurosciences and cognitive psychology. While cognitive symbol processing models take their origin directly from "von Neumann architecture" computers and leave to neurosciences the physical description of implementation, connectionist models propose mathematical formalisms that account for this implementation in terms of dynamic systems. A different interpretation of classical, cognitive models and of connectionist models leads to the conclusion that a strict boundary between neural and symbolic levels is unwarranted. 